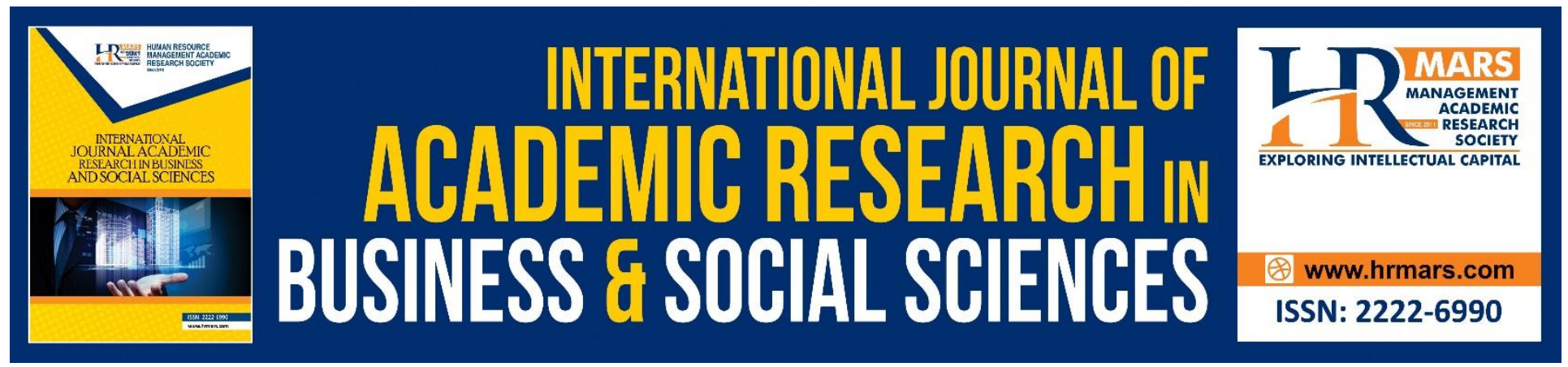

\title{
Women Fiqah Issues in the Book of Fiqh Ibadat Haji, Umrah dan Ziarah Issued by Malaysian Hajj Board: A Ta'siliyah (Foundational) Study Based on Al-Qur'an Al-Karim
}

Hasanulddin Mohd, Jamalluddin Hashim, Wan Mohd Khairul Firdaus Wan Khairuldin, Engku Ahmad Zaki Engku Alwi, Normadiah Daud

To Link this Article: http://dx.doi.org/10.6007/IJARBSS/v8-i10/4748 DOI: $10.6007 /$ IJARBSS/v8-i10/4748

Received: 23 Sept 2018, Revised: 17 Oct 2018, Accepted: 21 Oct 2018

Published Online: 31 October 2018

In-Text Citation: (Mohd, Hashim, Khairuldin, Alwi, \& Daud, 2018)

To Cite this Article: Mohd, H., Hashim, J., Khairuldin, W. M. K. F. W., Alwi, E. A. Z. E., \& Daud, N. (2018). Women Fiqah Issues in the Book of Fiqh Ibadat Haji, Umrah dan Ziarah Issued by Malaysian Hajj Board: A Ta'siliyah (Foundational) Study Based on Al-Qur'an Al-Karim. International Journal of Academic Research in Business and Social Sciences, 8(10), 462-470.

Copyright: @ 2018 The Author(s)

Published by Human Resource Management Academic Research Society (www.hrmars.com)

This article is published under the Creative Commons Attribution (CC BY 4.0) license. Anyone may reproduce, distribute, translate and create derivative works of this article (for both commercial and non-commercial purposes), subject to full attribution to the original publication and authors. The full terms of this license may be seen

at: http://creativecommons.org/licences/by/4.0/legalcode

Vol. 8, No. 10, 2018, Pg. 462 - 470

http://hrmars.com/index.php/pages/detail/IJARBSS

JOURNAL HOMEPAGE

Full Terms \& Conditions of access and use can be found at http://hrmars.com/index.php/pages/detail/publication-ethics 


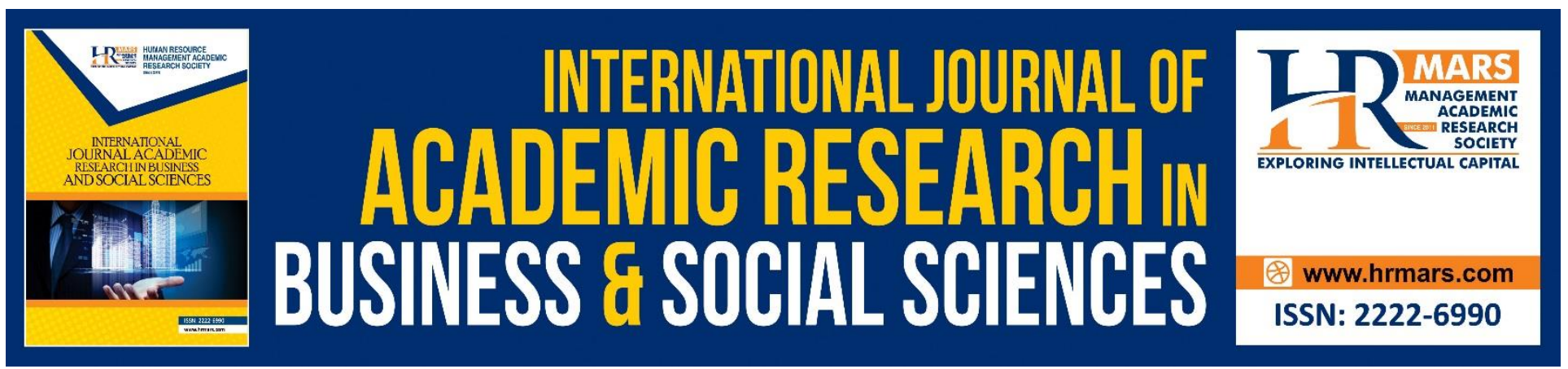

\title{
Women Fiqah Issues in the Book of Fiqh Ibadat Haji, Umrah dan Ziarah Issued by Malaysian Hajj Board: A Ta'siliyah (Foundational) Study Based on Al-Qur'an Al- Karim
}

\author{
Hasanulddin Mohd, Jamalluddin Hashim, Wan Mohd Khairul Firdaus \\ Wan Khairuldin, Engku Ahmad Zaki Engku Alwi, Normadiah Daud \\ Faculty of Islamic Contemporary Studies, University of Sultan Zainal Abidin, Terengganu, Malaysia
}

\section{Abstract}

The book of Fiqh Haji, Umrah dan Ziarah (Islamic Jurisprudence of Hajj, Umrah and Visit) is a book of Malaysian Hajj Board that deals with the rules related to hajj and umrah based on Shafie's school and the decision of the National Level Hajj Muzakarah. Although the size is quite small, this book is among the most important references to Malaysian pilgrims. Among the most important topics discussed are the Islamic Jurisprudence issues of the pilgrimage and umrah related to women. This is because women pilgrims represent a considerable proportion of who perform the worship each year. Various problems and complex issues involve them and need to be resolved as best as possible for their benefits of worship. This paper aims at highlighting the issues of hajj and umrah which focus on women's problems. It uses documentation method or document analysis in collecting related data. Next, it is analyzed by content analysis based on al-Quran al-Karim as the first source of Islamic law. The study found that all issues discussed were indeed in accordance with Islamic law based on the arguments agreed upon in Islam. However, not all of these arguments, including the al-Quran revealed. This is because the book is more specific to pilgrims who are mostly civilians. They are not obliged to know any arguments to the laws of Islam that they wish to practice. In conclusion, specific Islamic Jurisprudence issues such as women's issues should be emphasized and reinforced by the delivery approach in various mediums so that their targets will benefit from it.

Keywords: Book of Fiqh Haji, Umrah dan Ziarah, issues of women Islamic Jurisprudence, dirasah ta'siliyyah from al-Quran al-Karim.

\section{Introduction}

Book Fiqh Haji, Umrah dan Ziarah is a book published and updated by Lembaga Tabung Haji since 2006. Prior to that, haj and umrah guide books have been in existence for a long time. Its content 
speaks of the laws governing the pilgrimage and umrah based on Syafie's school and the decision of the National Level Hajj Muzakarah. Although the size is relatively small, the book is the most important reference to the pilgrims of Malaysia, as well as the Figh Haji, Umrah dan Ziarah book which have also been published by Lembaga Tabung Haji since 1984. In line with the ever-changing and complex haj and umrah issues, this book is constantly being reproduced and refined from time to time. Starting its publication in 1984, it has been reprinted 16 times with the latest print is in 2018. It has also been updated 3 times in 2013, 2015, 2016 and 2017. This clearly shows Tabung Haji's sensitivity to provide medium knowledge and information is best for benefits of pilgrims so that they can perform hajj, umrah and others perfectly with the haj pilgrimage. Among the most important topics discussed are the figh issues of the pilgrimage and umrah related to women. This is because women pilgrims represent a considerable proportion of who perform the worship each year. Various problems and complex issues involve them and need to be resolved as best as possible for the sake of their worship.

\section{Methodology}

In this regard, the paper is aimed at highlighting the issues of figh hajj and umrah which focuses on women's issues discussed in the Fiqh Haji, Umrah dan Ziarah. This is because the book is one of the most important medium of Hajj and umrah law by Lembaga Tabung Haji to pilgrims. This election was made to look at the Tabung Haji Board's sensitivity to legal issues involving women pilgrims as discussed by the book, as well as the influence of Shafie's sects and other sects on the election of the law being discussed. The authors use the documentation method or document analysis in collecting relevant data. In some cases, interview methods will also be conducted, especially for data not available through the documentation. It will then be analyzed using the method of analysis of the content and comparison in producing the appropriate findings and formulas. In the method of research of Islamic studies, he is particularly known as manhaj ta'siliyy (analyzing a fact to his original source) and istiqra'iyy (researching one by one before making the conclusion). This study is expected to contribute a small share of the issues raised, as well as to bring the reader to analyze the legal issues presented in the writing scientifically and critically based on al-Quran al-Karim.

\section{Background Book Writing}

Writing Purpose

The purpose of this writing was expressed in the welcome speech of the Group Managing Director and Tabung Haji Chief Executive Officer Datuk Seri Johan Abdullah: "This book has been arranged in accordance with the topic of pilgrimage haj for easy understanding of its contents. I believe this new, more robust and easy-to-understand version will help pilgrims during their pilgrimage and umrah during their stay in the Holy Land .... I hope this book becomes a useful reference source in giving a deeper understanding of the congregation pilgrims in their quest to achieve the perfection of the pilgrimage and to obtain a pilgrimage, in Allah (Jaya 2017, xii-xiii). "

This desire looks relevant and realistic with the important role that this book plays. It is certainly very useful and is a major reference not only for pilgrims, but also referred by pilgrims in solving the problems faced by pilgrims who are guided by them. 


\section{Authorship}

Book of Fiqh Haji, Umrah dan Ziarah is not authored by one person only. There are two committees and special preparation panels to ensure that they are able to achieve the goals and objectives set out. Its first committee is the Hajj Advisory Committee (Tabung Haji / JAKIM). They consist of:

i. Dato Seri Haji Hassan Ahmad (former Chairman of JPIH, where he has now been replaced by SS Datuk Dr Zulkifli Mohamad al-Bakri)

ii. Dato 'Haji Nooh Gadut

iii. Dato 'Haji Fadzil Haji Awang

iv. Dato 'Haji Wan Mohamad Dato' Sheikh Abdul Aziz

v. SS Datuk Dr Zulkifli Mohamad al-Bakri

vi. Associate Professor Dr Hajah Raihanah Haji Azahari

vii. Dr Anisah Abdul Ghani

viii. Dr Shamsiah Mohamad

ix. YM Tengku Aziz Raja Abdullah (Secretary)

The second committee is the Book Preparation Panel led by Dr. Juanda bin Jaya, while its members comprise:

i. Haji Mohd Sirajuddin Siswadi Putera bin Haji Mohamed Shith

ii. Haji Rosli bin Othman

iii. Haji Jamalluddin bin Hashim

iv. Haji Che Kamarudin Kamel bin Che Muhammad

v. Haji Zaini bin Zair

\section{Contents of Book of Fiqh Haji, Umrah dan Ziarah at a Glance}

Book of Fiqh Haji, Umrah dan Ziarah is written and arranged according to certain sections, chapters and topics. There are two main sections found in this book. The following sections describe the sections and the chapters contained therein briefly:

i. Part 1: Tell about the Hajj. There are 9 main chapters in this section as follows:

Chapter 1: Introductory Hajj. It encompasses the definition of Hajj, the law and the compulsory Hajj, the superiority of pilgrimage and the practice of the Hajj Rasulullah SAW. Also discussed are ethics before and during the pilgrimage, obligatory requirements, pilgrims and pilgrimage.

Chapter 2: Pillars of Hajj. It covers the sixth definition and pilgrimage, namely the pilgrimage, wuquf, pilgrimage and its types, hajj pilgrims, shaving or hairdressing and ordering most of the pilgrimage.

Chapter 3: Obligatory Hajj, which deals with the definitions of the Hajj and the matters contained in it, i.e. performing ihram in miqat, abandon the ihram ban, mabit (stay) at Mudzalifah, mabit at Mina, throwing at Jamrah Kubra and throwing in all three hammers.

Chapter 4: Tahallul and Nafar

Chapter 5: How to perform Hajj according to the types of Tamattu', Ifrad and Qiran.

Chapter 6: Dam (charges) and its divisions. Talk about the definition of dam and its four types.

Chapter 7: Women's problems in Hajj and umrah worship. Will be dealt with in the next sub topic. 
Chapter 8: Taharah and prayers. Contains topics such as ablution, tayamum, sahibul jabirah and related issues of prayer in holy land or on the way.

Chapter 9: Manners and how to maintain the pilgrimage. It is a complementary chapter to the pilgrimage that should also be given attention.

ii. Part 2: Debating the Worship of Umrah and Pilgrimage. There are 5 main chapters in this section as follows:

Chapter 1: Introduction to Umrah Worship. It encompasses the definition of umrah, legal and compulsory hajj, manners before and during the umrah and compulsory umrah.

Chapter 2: Rukun Umrah. It includes the five definitions and tenets of umrah, ie umrah's intentions, tawaf umrah, saie umrah, shaving or hairdressing and orderly in all rukun.

Chapter 3: Obligatory Umrah, which deals with the definite umrah definition and the matters contained in it ie intend ihram in miqat and abandon the ihram ban.

Chapter 4: Makkah al-Mukarramah. Tells the geographical position of Makkah, its history, the Haram Mosque, Kaabah, mas'a, zamzam water, the advantages and honors of the holy land of Makkah, Masya'ir Haram and the pilgrimage sites around Makkah.

Chapter 5: Al-Madinah al-Munawwarah. Tells the geographical position of Medina, its history, the Medina earth's edge, the Medina pilgrimage that includes the Nabawi Mosque and the place of Medina's history and manners during pilgrimage.

All of the topics in this book have been successfully fostered by a book-providing panel with the support of arguments from the Quran, the hadiths and the opinions of the scholars. Attractive and appropriate illustrations and illustrations are also attached to facilitate readers' understanding. This makes this book a mandatory and important reference for Malaysian pilgrims who want to perform hajj and umrah in the near future.

Table of Contents Book of Figh Haji, Umrah dan Ziarah Related to Women's Islamic Jurisprudence Issues and Analysis based on al-Quran al-Karim

The contents of the book of Figh Haji, Umrah dan Ziarah related to women's Islamic Jurisprudence issues have been briefly addressed in the previous sub-topics. It is stated in Part One, Chapter Seventh, which is during the discussion of hajj pilgrimage. There are eight sub-topics in this chapter. Details will be submitted later. Book of Fiqh Haji, Umrah dan Ziarah is written and compiled based on several references, especially fiqah books authored by al-Shafi'i scholars and some additional references from other schools. This al-Shafi'i sect has its own methods in the making of its recitation in its fiqh debates. Among them, the writings were found to be lesser than the Quranic verses, hadiths, al-ijma', al-qiyas and other arguments to discuss a problem. It was filled with the opinions of scholars in the school and discussed by comparing these opinions to the elected opinion. This is done as a science of comparative figh but within the scope of the neighborhood of the al-Shafi'i sect alone (Hashim, 2011).

Similar approaches are also made in this book, from the point of not including the arguments, especially from the Quran. This is in line with the original purpose of the book's writing, which is to 
provide knowledge and understanding to the public who want to perform Hajj and umrah. They do not need complete supporting arguments, enough to know some of the laws and details. However, this paper will try to analyze the hajj and umrah issues involving women pilgrims based on al-Quran al-Karim to provide added value to the writing of this book. This is because some of the pilgrims especially those who are religious educators need these arguments to calm their hearts, as well as to make further reference to the proposition if they are capable.

\section{Mahram}

Discussions about the mahram began with the hadith which asserted claims against women to take mahram as their traveling companions who were more than two pilgrims including pilgrimage and umrah. However, the Shafi'e sect relaxes this law if the woman is accompanied by a female pilgrim who is also confident of her safety. Also included is a mahram diagram for a woman so she can provide the right friend when needed. The demand for female pilgrims to provide mahram as a true friend is included in the terms of the ability to perform a pilgrimage, which is one of the requirements of the pilgrimage. Allah SWT says:

Mafhum: ... Allah obligates man to perform Hajj worship by visiting the House of Whoever is able to reach Him. And whosoever disbelieves, verily Allah is Rich (of necessity) of all creatures. (Ali 'Imran: 97)

This verse reinforces the support of the hadith brought by this book. This is because any woman who is not with her mahram as her traveling companion, then the condition of the ablution is fallen from her (Zaydan, 2000).

The consent of a husband or guardian

The law explained to ask the husband or guardian permission for women who want to perform Hajj or umrah. Also the attitude should be taken by the husband or guardian if asked for permission by wife or woman under his care. The related verses of the Qur'an are as above. This is because the consent of a husband or guardian is an additional requirement for a woman's ability to perform a pilgrimage.

\section{Women in idah}

There are two idah discussing the death of husband and idah raj'ie. Every idah has a specific law regarding the necessity to go on pilgrimage. In explaining the rules of the law for the woman of her husband's death, Allah SWT said:

Mafhum: Those who have passed away among you, while they leave wives should be restrained by them for four months and ten days. Then when the time has come to an end, there is no harm in you concerning what they do to themselves in a good way (approved by the Prophet). (Remember) Allah knows best whatsoever ye do. (al-Baqarah: 234)

For the divorced wife raj'ie, Allah SWT asserted: 
Mafhum: The divorced wives shall wait for their detention (from wedlock) for three occasions (from menstruation). And it is not lawful for them to conceal a son whom Allah hath created in their wombs if they believe in Allah and the Last Day. (al-Baqarah: 228)

Women's safety

Since traveling to a remote and crowded place, women's pilgrims need to ensure their safety every time they leave their property. Appropriate measures should be taken for that purpose. In order to avoid harmful things, Allah SWT has said:

Mafhum: And spend of it for the Religion of Allah, and do not throw yourself in the danger of mischief. and do well (with the best of your efforts and) your deeds; for Allah loves those who do good. (alBaqarah: 195) 4.5 Association of female pilgrims Just as in everyday life, women's congregations should take care of manners and limitations of their relationships, their gratitude and behavior to avoid causing slander. Allah SWT says:

Mafhum: And say to the believing women to restrict their view (from looking at the unlawful), and guarding their honor; and let them not show their jewelry except that which comes from them; and let them close the hem of his robe with their veils; and they should not show their body jewelry except to their husbands, or their father or their father-in-law or their children, or their stepchildren, or their brothers, or children of their brothers, or children for their female relatives, or Muslim women, or their slaves, or the salaries of men who are old and unwilling to women, or children who have yet to understand about the woman's aurat; and let them not stomp their feet to know what is hidden from their jewelry; and turn to Allah, O ye who believe! That ye may prosper. (Al-Nur: 31 )

Front restrictions

Also discussed is the limitations of the face of women during tawaf and prayers. This is because both of these rituals require women to cover their nakedness perfectly, just as well as outside. There is an exception for women who are in ihram to cover some of their faces to cover their heads. The discussion of Quranic verses on women's aurat has been mentioned in the previous subtopics.

Haid, postpartum and istihadah

The debate about menstruation, postnatal and istihadah topics is the longest and most interesting topic regarding women's issues. This is because it often happens and often involves complex issues. Discussions include periods of menstruation and puerperium, blood coming out day by day, color and nature of menstrual blood, how to recognize the blood of istihadah and practice during menstruation, postpartum and istihadah. Regarding the law of menstruation, Allah SWT has said (Ismail 2017, 30): Mafhum: And they ask thee concerning menstruation. say: "The menstrual blood is an object that (disgusting and) harmful." Therefore keep away from the woman (not marrying your wives) in the period of the period of menstruation, and do not come near them (for sexual intercourse) before they are holy. then when they have purified then come to them according to the way which Allah hath commanded you. Lo! Allah loves those who turn to repentance, and love those who purify themselves. (al-Baqarah: 222) 
Prayer Prayers and Friday Prayers

The discussion on prayer prayers ranges from the law of necessity to doing so for women with certain conditions. This is in line with the holy land that is always crowded especially during the haj season. Hence, there are certain restrictions that female pilgrims should adhere to in order to accept their practices, besides not inviting sin. In this case Allah Almighty has said:

Mafhum: O children of Adam! Use your beautiful dress to decorate each time you go to the place of worship (or pray), and eat and drink, and do not be too extreme; Indeed, Allah does not love the transgressors. (al-A'raf: 31)

Meanwhile, in the issue of Friday prayers, the fuqaha have indicated that women are not obliged to fulfill it as much as the obligations of men. Allah SWT says:

Mafhum: O you who believe! When the azan is called for the Prayer on Friday, then go straight to the Memorial to Allah and leave behind (for sale); That is good for you, if you know (the truth) (al-Jumuah: 9)

If the women still want to do so, then Zuhur prayer is no longer necessary. However, it is more important for them to perform Zuhur prayers at their respective homes to avoid any defamation and difficulty.

\section{Conclusion}

The Book of Fiqh Haji, Umrah dan Ziarah has successfully debated issues related to women fiqah thoroughly and comprehensively even in relatively limited debates. The debate put forward is in keeping with the customs of figh scholars in the al-Shafi'e sect, as well as the panel of authors also have a relatively flexible approach when discussing certain legal issues, particularly those involving women hajj pilgrims. The analysis based on the al-Karim al-Quran presented is only to add value to this book so that its readers can take advantage of it.

\section{Acknowledgement}

This article is part of a research titled: Metode Bimbingan Haji Oleh Lembaga Tabung Haji: Analisis Terhadap Modul Penerbitan Dan Cadangan Penambahbaikan (Guidance of Hajj Methods By Hajj Fund Board: Analysis Of Publishing Module And Recommendation Proposition) and it was funded by the University Research Fund (DPU), Project Reference Number: UniSZA/2017/SRGS (26). Special thanks to the University of Sultan Zainal Abidin for funding the research.

\section{Corresponding Author}

Assoc. Prof. Dr. Hasanulddin Mohd

The Faculty of Contemporary Islamic Studies

The University of Sultan Zainal Abidin

21300, Kuala Nerus, Terengganu Darul Iman.

Email: hasandin@unisza.edu.my 
INTERNATIONAL JOURNAL OF ACADEMIC RESEARCH IN BUSINESS AND SOCIAL SCIENCES

Vol. 8, No. 10, Oct. 2018, E-ISSN: 2222-6990 @ 2018 HRMARS

\section{References}

Zaydan, A.K. (2000). Al-Mufassal fi Ahkam al-Mar'ah wa al-Bayt al-Muslim fi al-Shari'ah alIslamiyyah. Beirut: Muassasah al-Risalah.

Hashim, J. (2011). Kitab al-Sirat al-Mustaqim Karangan Shaykh Nur al-Din al-Raniri (Kitab al-Taharah dan al-Salah): Teks dan Analisis, PhD Dissertation, Akademi Pengajian Islam, Universiti Malaya.

Ismail, M. (2017). Izalatul Iltibas fi Syarh Tuhfat al-A'izza'. Kuala Lumpur: Dar Miftah al-Ulum 